\title{
Analysis of Socio-Economic Factors Affecting Fish Marketing in Igbokoda Fish Market, Ondo State, Ngeria
}

\author{
Agbebi F.O.*; Adetuwo, K. I. \\ Department of Fisheries and Aquaculture Technology, Faculty of Agriculture, Food and Natural, Ondo State University of \\ Science and technology, Nigeria \\ *Corresponding author
}

\begin{abstract}
The study analyzed the socio-economic factors affecting fish marketing in Igbokoda fish market, Ondo State, Nigeria. A purposive sampling technique was used in selection of the respondents. Sample size comprised eighty fish marketing households. Questionnaire was used for data collection. Results revealed that fish marketing in the area is dominated by females (88.7\%). Majority (91.3\%) were married with an average household size of 7 persons. Marketers earned an average income of $\$ 60,000$ per month. Majority (71.3\%) do not belong to cooperative societies, $46.3 \%$ of the marketers have an average of 16.5 years of experience. Findings also revealed that fish marketing is efficient and lucrative in the area. However, constraints faced by the marketers include; inadequate storage facilities, price instability, inadequate capital, lack of access to credit, distance to market among others. It was therefore recommended that effective agricultural policies and programs should address marketers' easy access to credits, infrastructural facilities such as good storage and processing facilities, electrification, good feeder roads should be provided in the area to reduce spoilage and unprofitable sales.
\end{abstract}

Keywords- Fish Marketers, Socio-economic Characteristics, Igbokoda, Nigeria.

\section{INTRODUCTION}

Fish production and marketing is one of the oldest livelihood income generating activities of man since the time immemorial. Fish contains high quality protein, vitamins, minerals and other nutrients important for human health and growth. According to Ovie and Raji (2006), fish is crucial to the Nigerian economy, contributing $5.4 \%$ of the gross domestic product (GDP). Fish are significant to the nation's economy in terms of food security, income, employment, poverty alleviation, foreign exchange earnings and provision of raw materials for animal feed industries.
Fish is the commonest and cheapest source of protein for the teaming Nigeria's poor, estimated to be between $65-70 \%$ of the total population. Fish is also a good source of Sulphur and essential amino acids such as lysine, leucine, valine and arginine and it is therefore suitable for supplementing diets of high carbohydrates contents (Amao et al., 2006).

It has high content of Polyunsaturated (Omega III) fatty acids, which are important in lowering blood cholesterol. FAO (2012) recommended that a person takes 35 grams per caput of animal protein per day for sustainable growth and development. Fish which contributes 36.6 grams per day of net protein utilization in Nigerian homes is still below the recommended requirement by the world health organization (WHO) (Ohen and Abang, 2009) Marketing is a process of exchanging goods and services from one person to another with reference to price. A fish market is a place used for marketing of fish and fish products. However, fish marketing essentially consists of all the activities involved in delivering fish from one producer to the consumer, while distribution provides channels that link the marketing institutions and producers together. The market mechanisms have to be efficient to be able to play the role of propelling yield. An efficient market system therefore is the one that provides satisfactory and cheap services to consumers or one that maximize the ratio of input and output of marketing. In Nigeria, fish system varies depending on type of fish product and the distance between producer and source of supply of fish product and retailer and ultimately to consumer. Fish supply and marketing suffer from various sets backs, ranging from shortage of supply, price fluctuation due to drying up of the source and spoilage in transit amongst others. Despite these, the agencies involved in the marketing of the commodity appear to be on the increase as a result of increase in the population and therefore, the demand tends to be high. Also despite the nutritional and commercial values of fish and fish products, 
its production and marketing remains low in Nigeria when compared to other nations of the world (FAO, 2012). Fish and fish products is consumed in all parts of the country and has a good market price. Often times, marketers are compelled if not forced to sell their product at a very low price to avoid huge wastage or total loss and this reduces their marketing margins and marketing efficiency.

Although, a number of studies have been carried out on fish and fish products in Nigeria, most of such studies dwelled on its production and consumption. Agricultural marketing is central to agricultural development and the overall growth and development of the economy. Previous studies have shown that efficient marketing system stimulates agricultural production (Awoyinka and Ikpi, 2005, Awoyinka, 2009). Efficiency in fish marketing has the potentials of stimulating fish production in the country in view of the huge deficit between local consumption and production. This will have a downward effect on the price of fish and thereby induce more consumption of fish by consumers. The importance of this development cannot be over-emphasized in country like Nigeria whose economy, life and wellbeing are immersed in agriculture, and fish alone constituted more than $40 \%$ of total protein intake in the country (Eyo, 1992). Major components of fish marketing efficiency are profitability and marketing margins of the various participants (i.e. wholesalers and retailers). Research has shown that there is continuous increase in the number of people involved in fish marketing as a result of growing population of the country (Ali et al., 2008). This is an inkling of the profitability of the enterprise as only profitable activities could be attracting increasing number of participants. Furthermore, the economy of Nigeria, just like other sub-Saharan African countries, is still developing. This has imposed a lot of challenges on marketing of goods and services in the country, especially agricultural products like fish. It has been argued that agricultural marketing is inefficient resulting in high rate of food spoilage, poverty and unaffordable food prices by consumers. However, not many studies have empirically evaluated the validity of these hypotheses in fish marketing.This study seeks to analyze economics of fish marketing and in so doing address questions affecting marketability of fish.

According to Adekanye (1988) and Abdullai (1983), marketing of food in Nigeria is characterized by multitudes of deficiencies and problems. These problems cut across processing, preservation, packaging, distribution and transportation Eze, et al (2010), identified inadequate processing skills, produce deterioration and lack of storage facilities as the major constraints perceived by women marketers. However, this may not be exhaustive bearing in mind the paucity of research in fish marketing, and also the rural nature of participants in fish marketing. According to (Adekanye, 1988), marketing is a method used to bring the interpersonal forces of demand and supply together irrespective of the location of the market. Application of various pricing criteria on sales of fish depend on efficiency with which the marketing system transmits information among the fish mongers or marketers and consequently, prices of fish changers as it passes through middlemen such that by the time it reaches consumers, it becomes expensive. Agbebi and Fagbote (2012) observed that middlemen are marketing intermediaries that do not add title to the products, but receives fee for expediting the exchange. Fish supply and marketing suffer from various setbacks ranging from shortage of supply, price fluctuation due to drying up of the source, spoilage in transit etc. (Tomek \& Robinson, 1981). Despite these, the individuals involved in the marketing of the commodity appear to be on the increase as a result of increase in the population and therefore, the demand tends to be high. Tomek and Robinson (1981) indicated that increase in concentration implies more scope for the middleman to exploit either the consumers by charging high or the producer by paying them lower price. Nigeria offers the largest market for fisheries products in Africa. Fish production from capture fisheries in spite of its being expensive and risky in the coastal line regions of Nigeria has been erratic and on the decline in recent years, resulting in increase in poverty and nutritional deficiency. Fish production and marketing remains the best option to bridge the gap between the total fish demand and total domestic production in the face of high cost of production input and unstable government policy. Therefore, the socioeconomic of fish marketing evaluates the structure, conduct and performance of fish marketing system as indicators of the overall efficiency of the system.

It is of essence in the determination of both consumers' living cost and producers' income and hence, the overall wellbeing and development of the country. , the study identified socio-economic characteristics of the marketers; ascertained marketing channels of fish in the area; determined the influence of the socio-economic characteristics of the fish marketers on their profits margins; determined marketing margin; determined marketing efficiency; examined the costs, return or profitability of fish marketing and identified constraints associated with fish marketing in the area.

\section{OBJECTIVES OF THE STUDY}


The broad objective of this study is to determine the socioeconomic factors affecting fish marketing in Igbokoda fish market, Ondo state.

The specific objectives are to:

i) To identify the economic constraints that affects the various fish Markets/settlements.

ii) Identify the nature, socio-economic structure of the market and investigate the potential for growth in the fish market and access the level of demand and consumer preference for different fish whether fresh, smoked, dried, ice or fried.

iii) Identify the factors affecting the quality and quantity of fish marketed in the study area.

iv) Make recommendation based on the findings of the study.

\section{METHODOLOGY}

\section{STUDY AREA}

Igbokoda fish market is located in Igbokoda, in Ilaje Local Government area of Ondo State, South-Western, Nigeria. This fish market is the largest fish market in the SouthWestern part of Nigeria in which fishing has been the dominant occupant of its inhabitants. The area has the Atlantic Ocean as its neighbour hence a lot of artisanal fishing is done in the area. The area also has a history of the active participation by women in fish production and also well located in relation to village downstream because it has a good road link to Akure, the capital city of Ondo State and to the other areas of Nigeria. Fishing, processing and marketing has been the dominant occupation in the area. The map of Ondo state and that of Ilaje local Government are shown in figure 1 and 2 respectively.

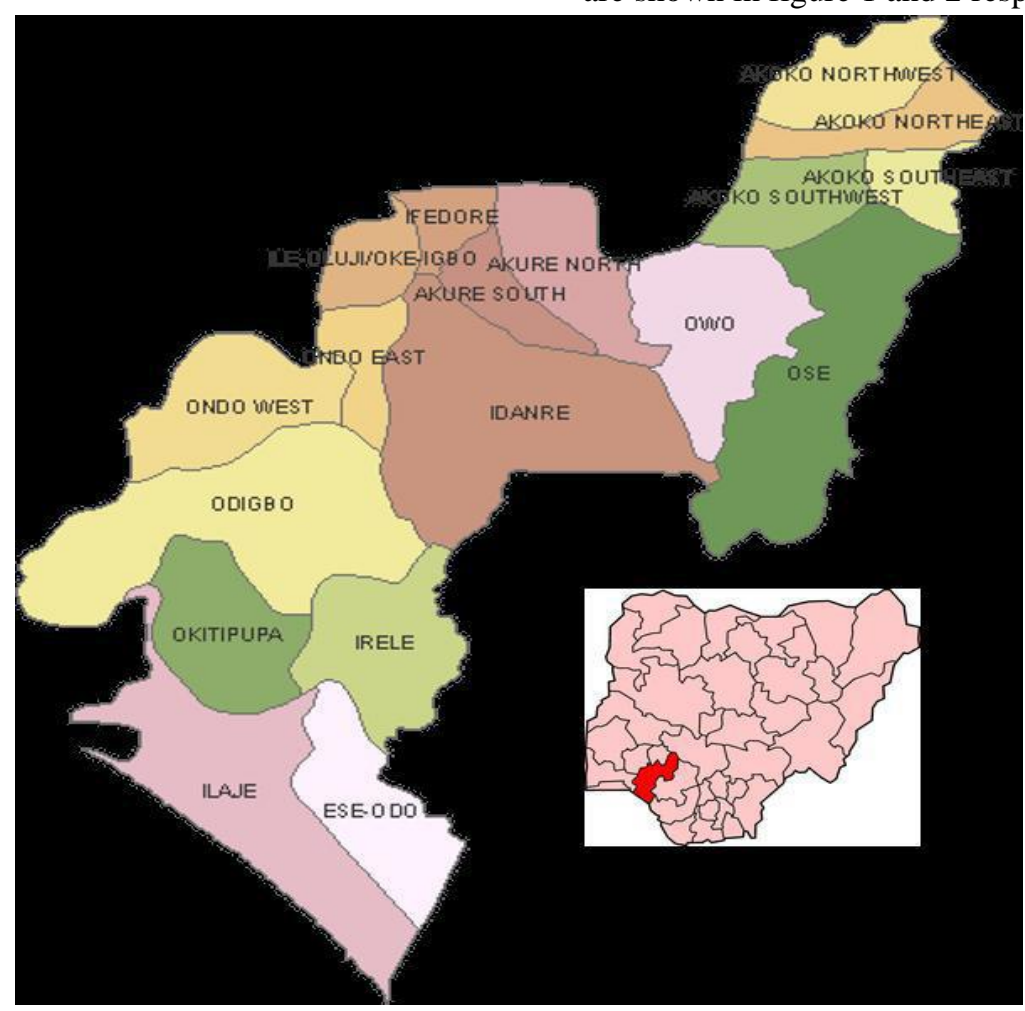

Fig.1: Map of Ondo state showing Ilaje Local Government area 


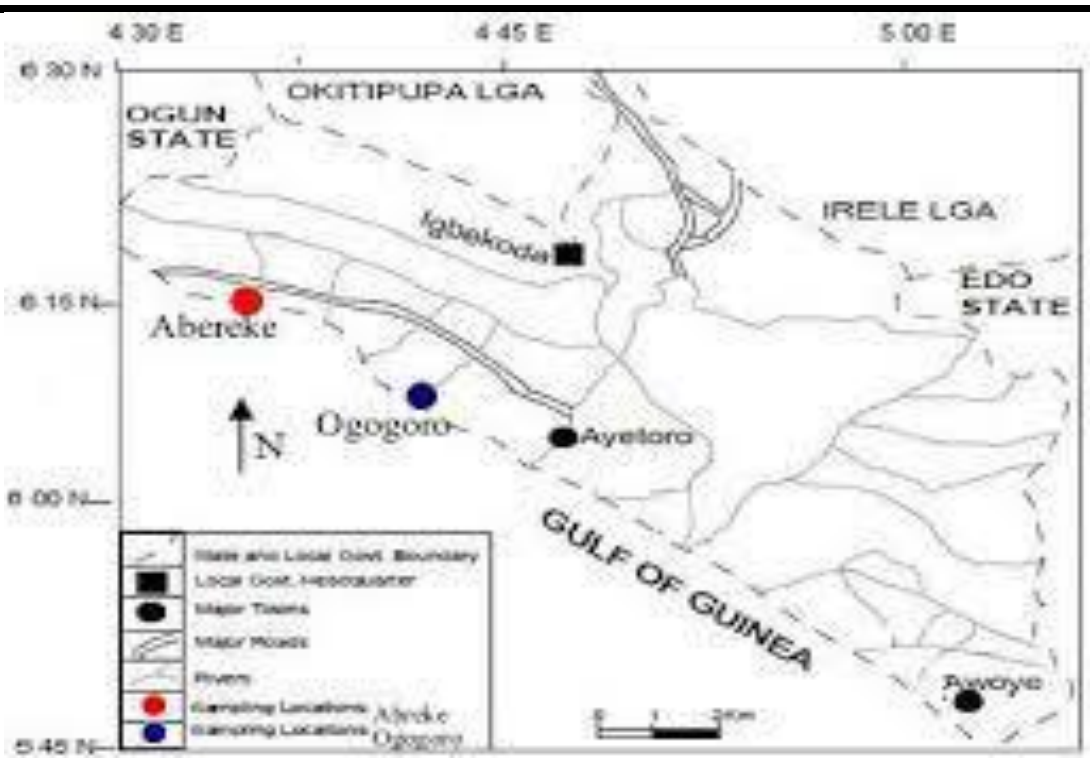

Fig.2: Map of the study area

\section{METHODOLOGY}

A total number of 80 respondents were used for the study. This study entails the use of questionnaires and personal interview with men and women involved in fish marketing activities. The personal interview focused on problems and challenges faced by fish marketers from the middlemen as well as major challenges of the fish market. Purposive sampling technique was used to select respondents for this study. The main tool for data collection was a set of structured questionnaire in addition to oral interviews in places where the respondents could neither read nor write. The questionnaire sought for information on socioeconomic characteristics of the fish marketers, quantities of fish purchased, quantities of fish sold, costs associated with fish marketing and the associated problems.

\section{RESULTS}

The results presented in Figure 1 shows the age distribution of fish marketers in the study area. $21.2 \%$ of respondents ${ }^{\text {ce }}$ were within the age range of 21-30 years, the average age of the marketers was 36 years while the minimum and maximum ages were 15 and 60years. Implication of these findings is that large proportions of the respondents were adults and can adequately be regarded as active, agile, and physically disposed to marketing activities. Age is very important in fish marketing activities because age has a significant influence on the decision making process of the marketers.

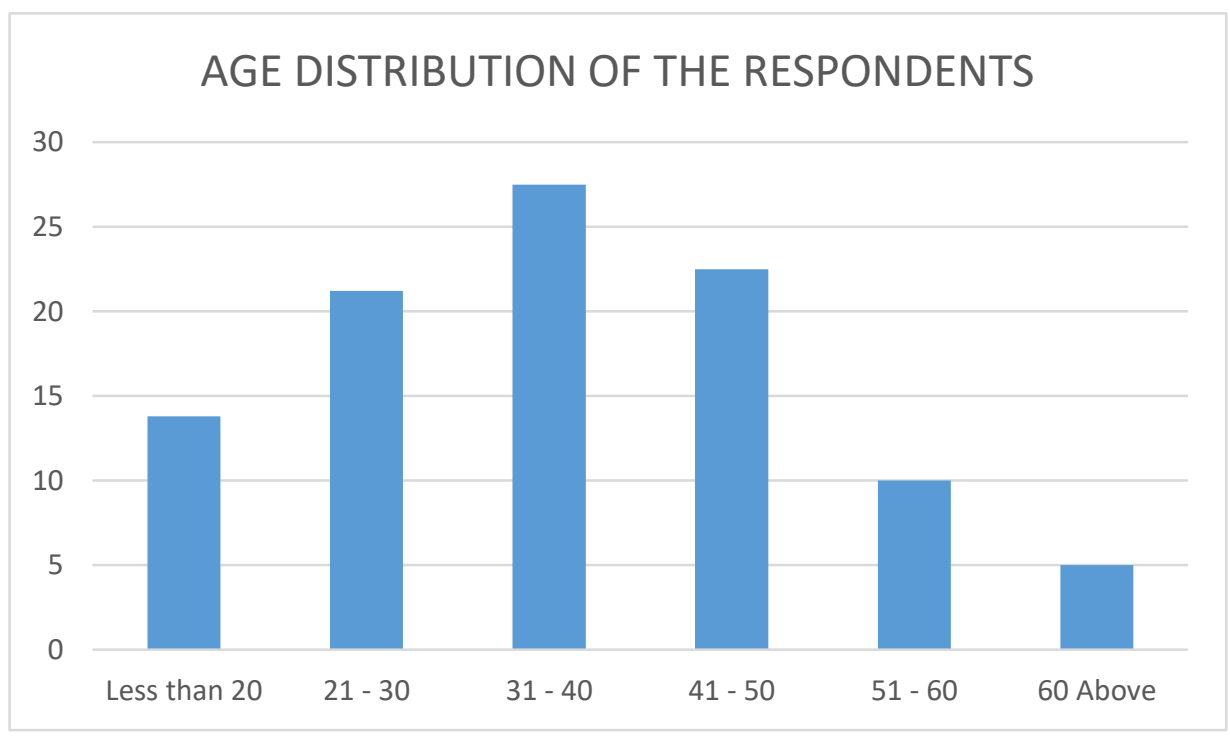

Fig.1: Age distributions of the respondents 


\section{Gender}

The result in figure 2 below shows that about $88.7 \%$ of the fish marketers were female while the $(11.3 \%)$ were male. The result is in line with the findings of Agbebi and
Fagbote, (2012) that fish marketers are more dominated by female gender than male and that women play a central role in fish processing and marketing and that women also have better bargaining power than men.

\section{Sex Distribution of the Respondents}

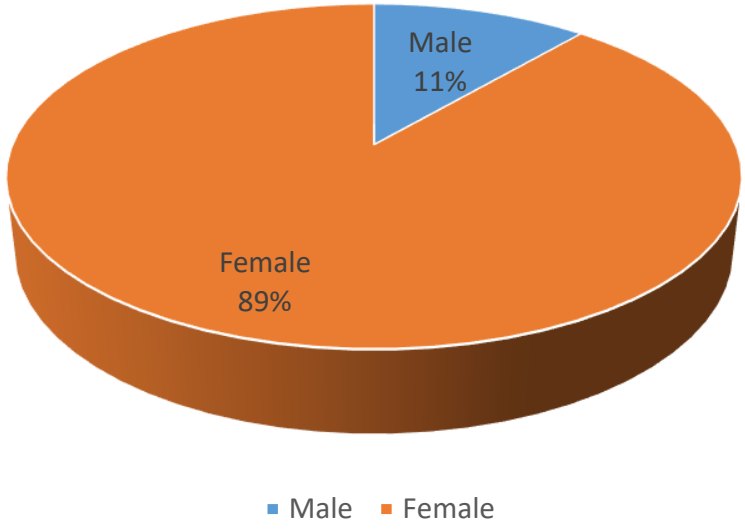

Fig.2: Distribution by gender

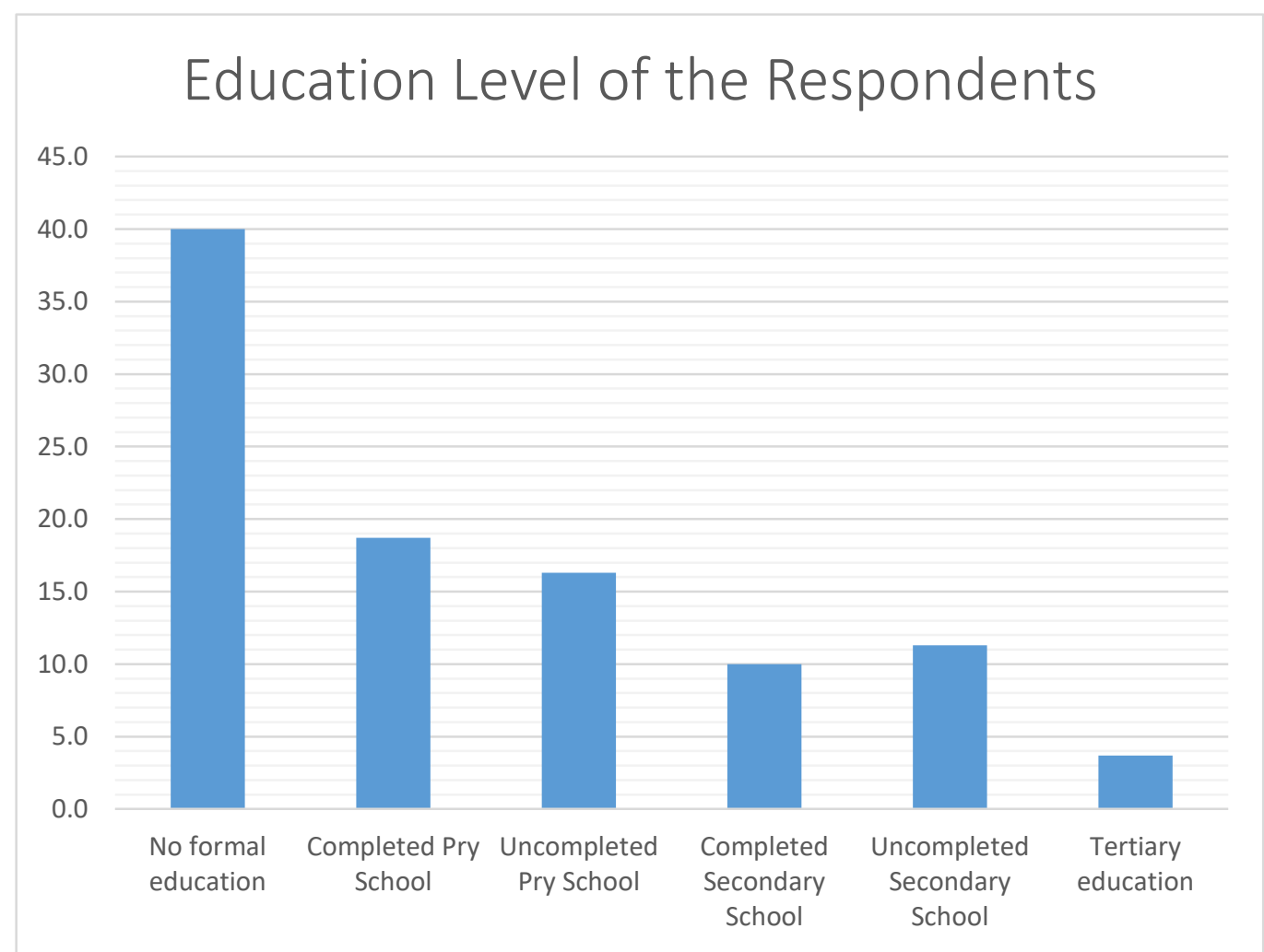

Fig.3: Educational level of Respondents

The result presented in Figure 3 shows the distribution of fish marketers by their educational level. The result indicated that about $40 \%$ of the fish marketers do not have access to formal education, which is an important factor and similar to the general believe that most marketers are illiterates or semi-illiterates most of whom dropped out of formal school system. It is also believed that a person level 
of education determines how fast and concise an individual will decode or process information.

\section{Marital Status}

The result indicated that about $5.0 \%$ are Single, $91.3 \%$ are married and $3.7 \%$ are widowed. This implies that fish marketing in the area is dominated by married individual who are responsible according to the society standard and therefore are likely to have some experience of life (Onubuogu et al., 2014).

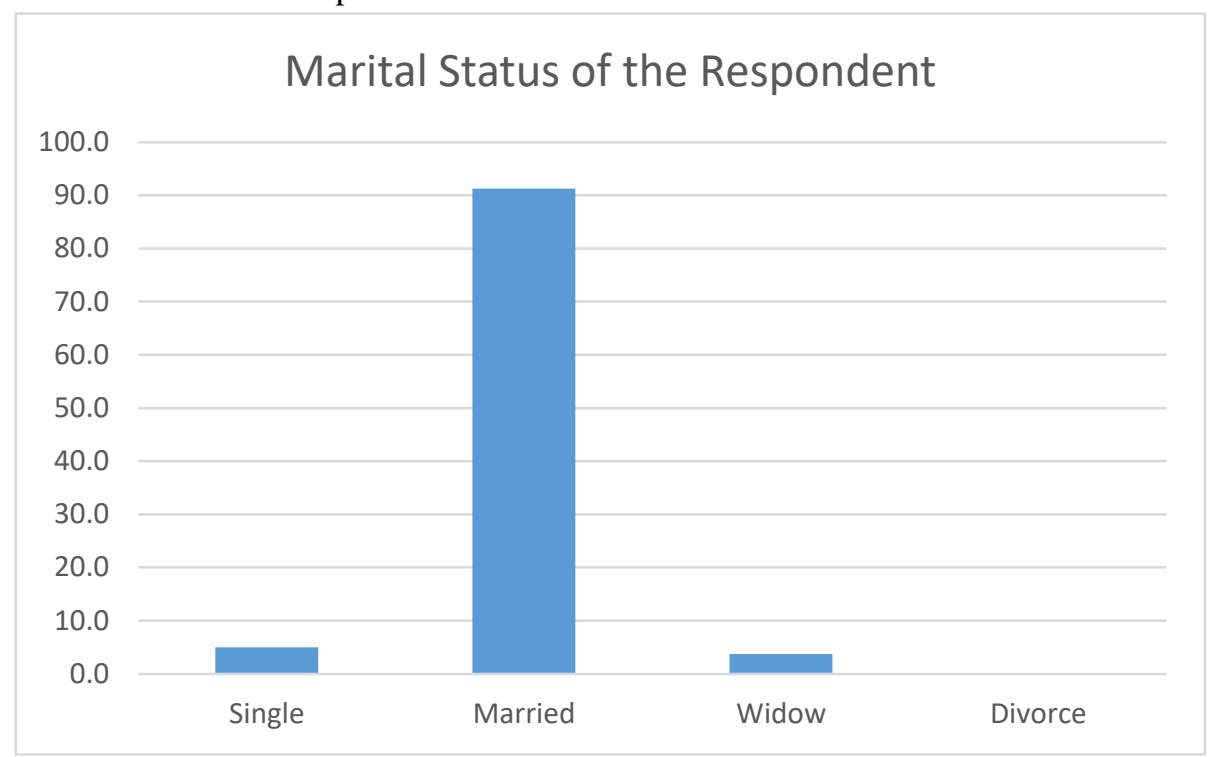

Fig.4: Marital status of respondents

High percentage of married individual is also an indication that the respondents are permanent settlers in the area and all their economic activities revolve around the area, so migration is not a case to be considered.

\section{Marketing Experience}

Greater proportion (46.3\%) of the respondents had 11-20 years of marketing experience, while $11.2 \%$ constitute those with 31 years of marketing experience and above in fish marketing. This implies that marketers in the study area have sufficient experience in fish marketing. Experience in marketing is a key factor in marketing efficiency and the longer the years of marketing experience, the more exposed the marketer becomes and the more efficient and effective the marketer is expected to be.

\section{Marketing Experience of the Respondents}

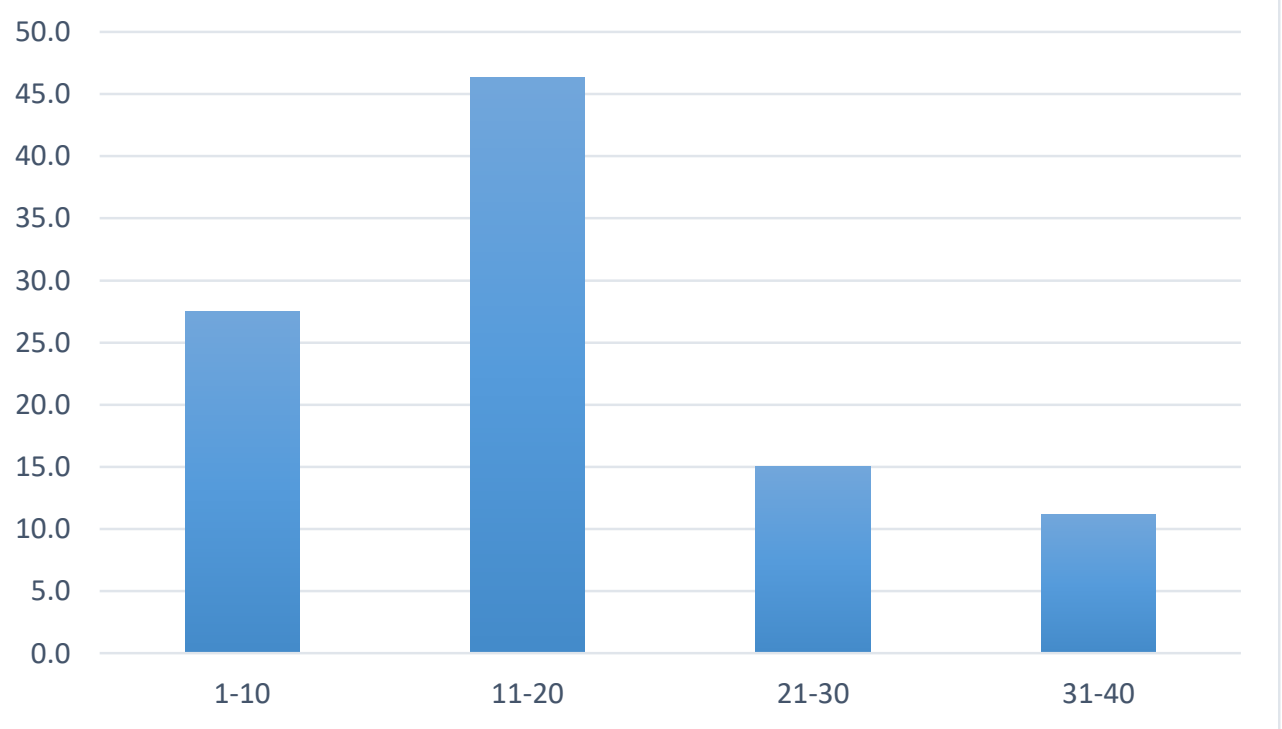

Fig..5: Marketing experience of the respondents 


\section{House-hold size}

A household comprises of all persons who generally live under the same roof and eat from the same pot (FOS, 1985; Esiobu et al., 2014a and Esiobu et al., 2014b). It can also be described as all people who live under one roof and who make or are subject to others making for them joint financial decision. Larger percentage $(46.3 \%)$ of the fish marketers had a household size of 6-10 persons which is an indication that fish marketers in the study area have a large household size and cheap access to un-remunerated family labour. This therefore explains why the use of hired labour in small scale agribusiness enterprise is very low.

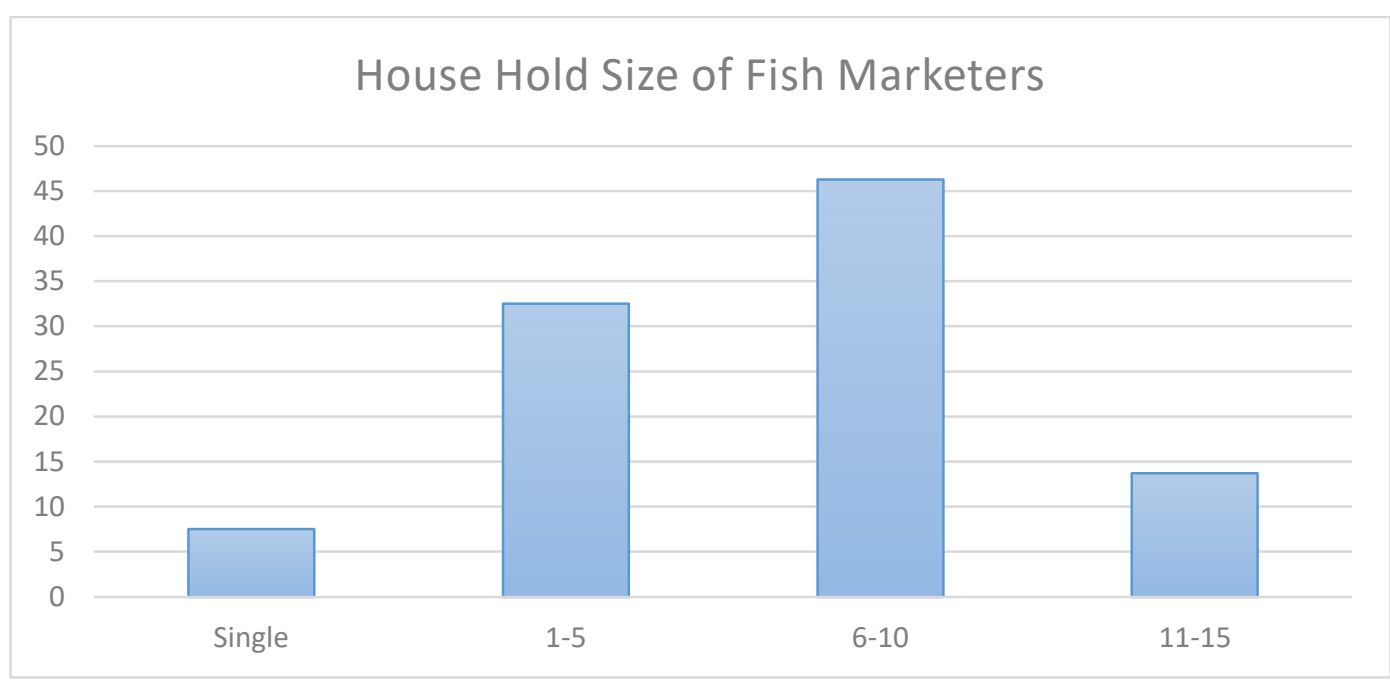

Fig.6: Household size of respondents

Table.1: Cooperative membership

\begin{tabular}{ccc}
\hline Cooperative Society & Frequency & Percentage \\
$\mathbf{N}=\mathbf{8 0}$ & & \\
\hline Non-members & 57 & 71.3 \\
Members & 23 & 28.7 \\
Total & $\mathbf{8 0}$ & $\mathbf{1 0 0}$ \\
\hline
\end{tabular}

\section{Years of Membership in Cooperative}

40

35

25

20

15

10

0
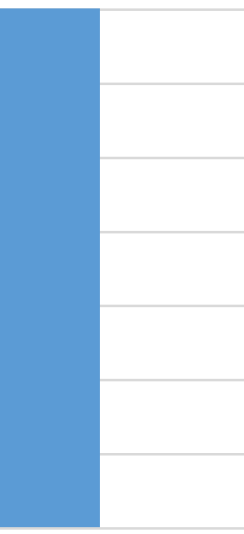

1-3 years

4-6 years

7-9 years

10-12 years

Fig..7: Years of cooperative membership 
Table 1 showed that majority $71.3 \%$ do not belong to any fish marketer's association. While only $28.7 \%$ belong to the cooperative association. Fig. 7 showed that majority (35.1\%) of the members has spent 4-6 years as a member. Membership of a cooperative society enables marketers to interact with themselves, share their experiences and assist themselves. The implication of these results is that most of the marketers in the study area do not enjoy the assumed benefits accruing to cooperative societies through pooling of resources together for a better expansion and effective management of resources which in most cases could not be derive individually.

\section{Monthly income of the Respondents}

Figure 8 showed that majority $(33.8 \%)$ of fish marketers make an average income between $\$ 41,000$ - $\$ 60,000$ while $12.5 \%$ make an average income of below $\$ 20,000$. Ultimately, weekly sales of fish are also presented It reveals that greater proportion $(36.2 \%)$ of the fish marketers sold at least 31 - 40 fishes per week. The implication of the findings is that the demand for fish consumption is significantly high in the study area. The result confirmed the evidence of the appreciable profit margin the marketers recorded as earlier found out in the study area.

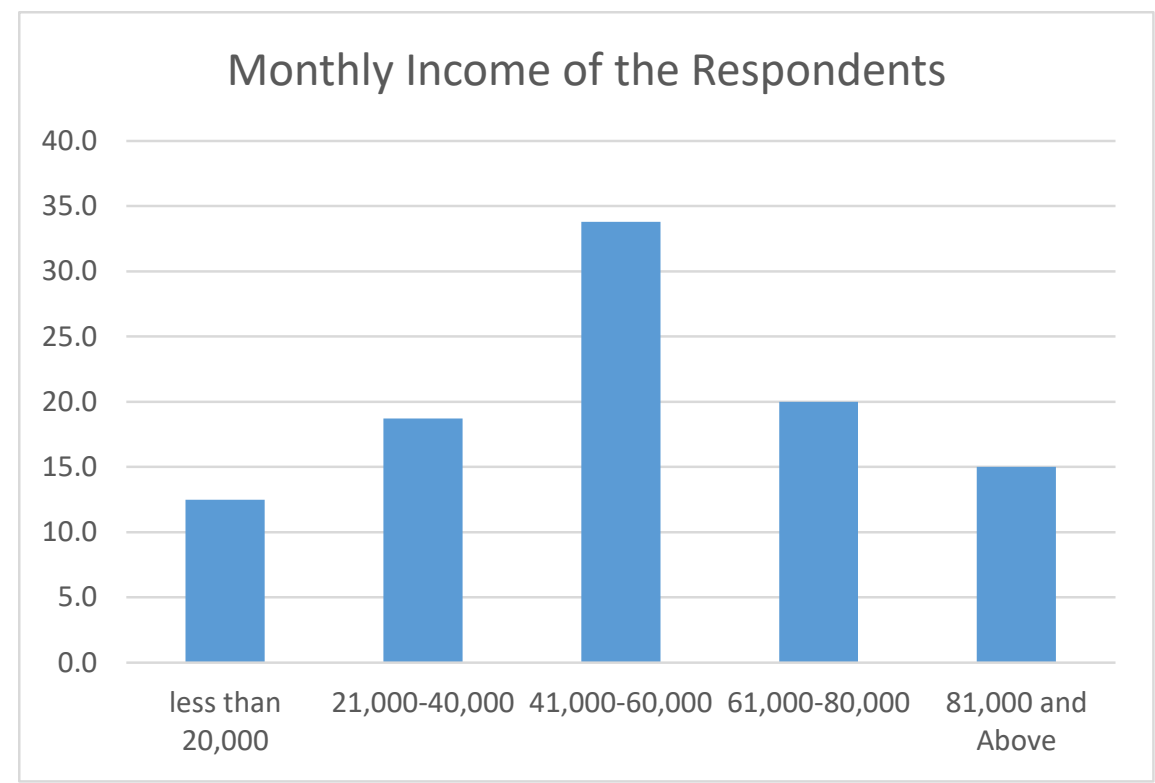

Fig.8: Monthly Income of Respondents

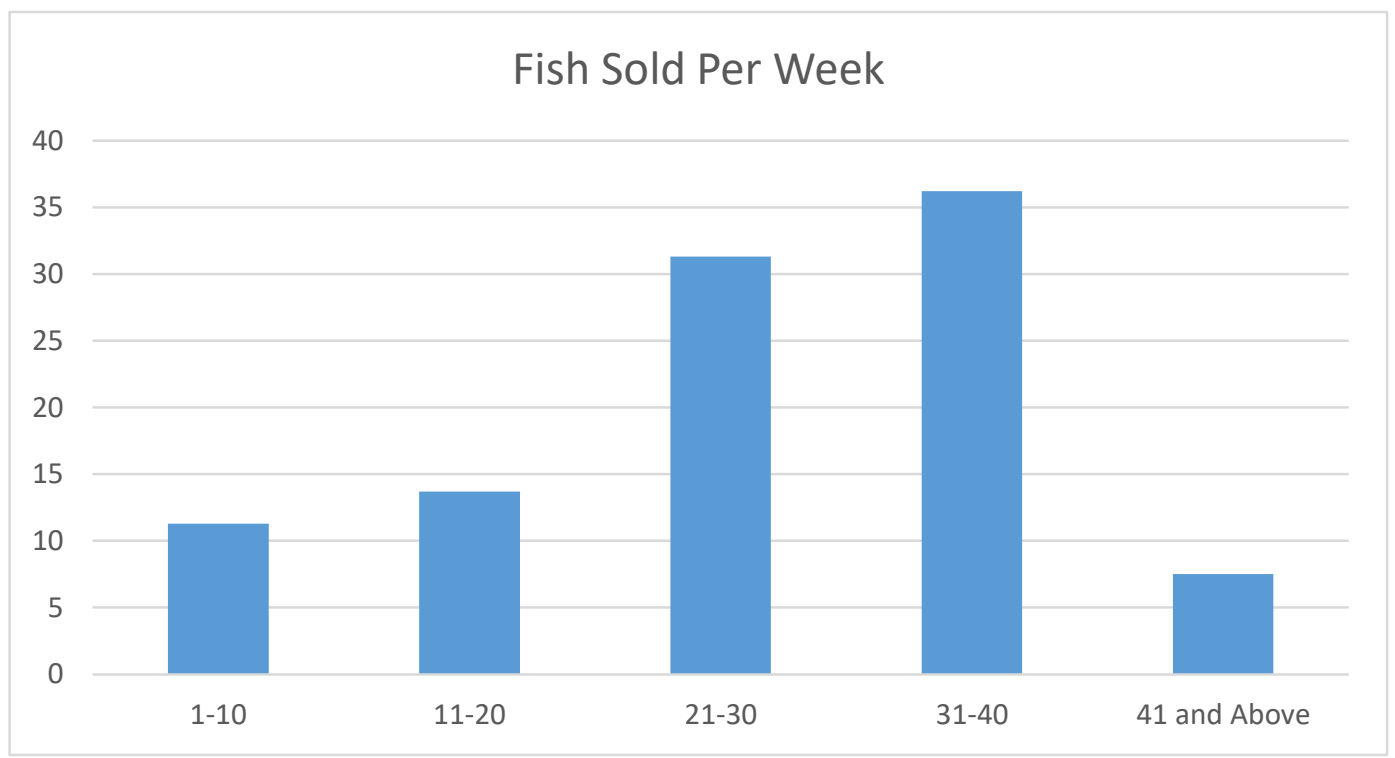

Fig.9: Fish sold per week 
Constraints Encountered by Fish Marketers in the study area

Nigeria's business sector in general as well as the fish subsector in particular has experienced some impediments which slowed the performance of the sector (Adegeye, and Dittoh, 1985). This has caused the output growth not to keep pace with its demand, thereby, resulting in declining exports and domestic supplies and a growing reliance on imports of the products. The problems faced by fish marketers in the study area were ranked according to their severity stated by the respondents. Figure 10 reveals that inadequate storage facilities were the most serious constraint faced by the fish marketers in the area as indicated by $90 \%$. The perishable nature of the fish is a severe barrier to fish marketers this could be attributed to non-electricity in the area which is highly needed for preserving fresh fish which is in high demand in the area.

Fresh fish could only be stored for few hours in which case must be sold even when the price is not favourable, this account for the severe losses suffered by fish marketers in the study area. Fish requires large amount of capital investment for reasonable profit to be made. The study also revealed that about $72.5 \%$ of the respondents attested to the fact that Price instability and price fluctuation of fresh catfish were the first constraint faced by marketers. This finding is in line with Bureau of Statistic (2012) that says Prices for fresh fish product responded to the law of demand and supply as no price regulation mechanism exists. $63.8 \%$ identified inadequate capital. Fish marketing requires large amount of capital investment for reasonable profit to be made over time. Inadequate capital hinders the marketers from getting the necessary marketing resources and technologies which will increase their profit margin and marketing efficiency. Fresh fish marketing resources are costly. High cost of transportation as a result of bad road network as indicated by $63.8 \%$. Lack of access to credit indicated by $58.8 \%$, ranked fourth on marketing problems limiting operation and expansion of marketing activities in the study area. The problem in accessing credit was mainly related to absence of collateral, high interest rate of commercial bank.

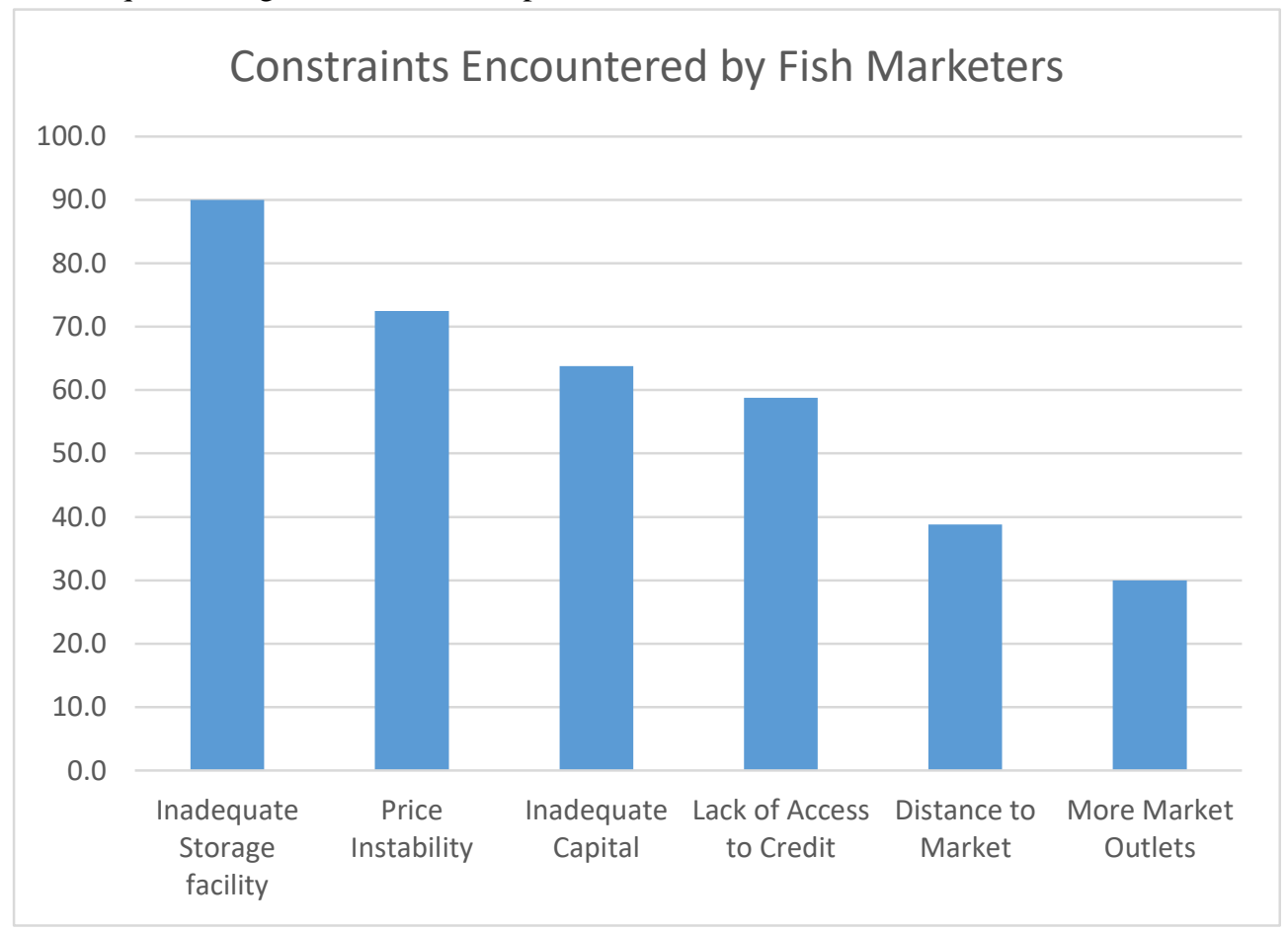

Fig.. 10: Constraints encontered by the respondents

\section{CONCLUSION}

Fish marketing is a lucrative enterprise in the study area. Analysis revealed that age, marital status, education, marketing experience, monthly income and membership of cooperative societies were found to be the significant factors influencing profit margin and the relationships were significant. Also in the study area most of the fish marketers are females and their ages were within the economic active range which favours adoption of marketing development. Most of the fish marketers are married and highly experienced in fish marketing because of families' inheritance. 


\section{REFERENCES}

[1] Abdullai, A. (1983). The role of agriculture in reversing the present economic crisis in Nigeria. A public lecture organized by Nigerian Institute of Social and Economic Research (NISER) delivered at University of Calabar, November, 25.

[2] Adegeye, A. J. and J. S. Dittoh (1985). Essentials of agricultural economics. Ibadan: Impact Publishers pp. 113-116.

[3] Adekanye, T. O. (1988). Readings in agricultural marketing. Lagos: Mexico Enterprises Ltd. Pp. 1, 2 and 12.

[4] Agbebi, F. O. (2010): Salient issues in fish marketing Systems in Nigeria, Journal of Environment issues and Agriculture in Developing Countries Vol. 2, No. 1, Pp. 94-103.

[5] Agbebi, F. O., Fagbote, T. A. (2012): The role of middlemen in fish marketing in Igbokoda fish market, Ondo State, Nigeria. Journal of Development and sustainability. Vol. 1, No. 3. Pp 88-97

[6] Ali, E. A., H. I. M. Gaya and T. N. Jampada (2008). Economic analysis of fresh fish marketing in Maiduguri Gamboru Market and KachallariAlau Dam landing site of North-eastern, Nigeria. Journal of agriculture and social sciences 6(2): 3-5.

[7] Amao, J. O., Oluwatayo I. B. and Osuntope F. K. (2006). Economics of Fish Demands in Lagos State, Nigeria. Journal of Human Ecology, 19(1): 25-30

[8] Awonyinka, Y. A. (2009). Cassava marketing: option for sustainable agricultural development in Nigeria. Journal of applied science, 2(2).

[9] Awoyinka YA, Ikpi AE (2005). Economics of Farm Income and Technical efficiency of Resources in Jigawa state industrial sugar cane project. 7(1): 12-16.

[10] Awoyinka, Y.A., 2009. Effect of presidential initiatives on Cassava production efficiency in Oyo State - Nigeria. Ozean J. Appl. Sci., 2(2): 185-193.

[11]Esiobu, N.S., Nwosu, C.S and Onubuogu, G.C. (2014). Economics of Pineapple Marketing in Owerri Municipal Council Area, Imo State, Nigeria. Int. J. Appl. Res. Technol.. 3(5): 3 - 12.

[12] Esiobu, N.S., Onubuogu, G.C and Okoli, V.B.N. (2014b). Determinants of Income from Poultry Egg Production in Imo State, Nigeria: An Econometric Model Approach; Global Advanced Res. J. Agric.l Sci. 3(7): 186-199.

[13]Eyo, A. A. (1992a). Fish handling, preservation and processing. A paper presented at the improved management for agricultural training at Federal College of Freshwater Fisheries Technology, New
Bussa between 22nd September and 23rd October 1992.

[14]Eze, S. O., A. N. Ezeh and E. A. Onwubuya (2010). Women marketers' perceived constraints on selected agricultural produce marketing in Enugu South Local Government Area: challenges of extension training for women groups in Enugu State, Nigeria. Agroscience journal of tropical agriculture, food, environment and extension, 9(3): 215- 222.

[15]FAO, 2012. The state of world fisheries and aquaculture. FAO Fisheries and Aquaculture Department, FAO, Rome, 2012

[16] Ohen, S.B and Abang, S.O. (2009).Economics of Catfish Farming in Rivers State, Nigeria; Acad. J. Plant Sci. 2 (1): 56-59, 2009 ISSN 1995-8986.

[17] Onubuogu, G.C., Esiobu, N.S., Nwosu, C.S. and Okereke, C.N (2014). Resource use efficiency of smallholder cassava farmers in Owerri Agricultural zone, Imo State, Nigeria; Scholarly J. Agric. Sci. 7(8):. $142-152$

[18] Ovie S. I. and Raji A. (2006). Fisheries CoManagement in Nigeria: an analysis of the underlying policy process. Niger State, Nigeria, National Institute for Freshwater Fisheries Research, 5Pp.

[19] Tomek, W. G. and L. Robinson (1981). Agricultural product prices, 2nd edition. Ithaca, New York, U. S. A.: Comel University Press. 